\title{
Developmental Characteristics, Genetic Compatibility and Esterase Zymograms in Three Strains of the Hawthorn Spider Mite, Tetranychus viennensis Zacher (Acari: Tetranychidae)
}

\author{
Tetsuo GOTOH and Kenji TAKAYAMA \\ Laboratory of Applied Entomology and Zoology, Faculty of Agriculture, \\ Ibaraki University, Ami, Ibaraki, 300-03 Japan
}

(Accepted 9 March 1992)

\begin{abstract}
Gotoh, T. and K. Takayama, 1992. Developmental characteristics, genetic compatibility and esterase zymograms in three strains of the hawthorn spider mite, Tetranychus viennensis Zacher (Acari: Tetranychidae). J. Acarol. Soc. Jpn., 1(1): 45-60.

Developmental success on 55 species of plant, traits of population growth, reproductive compatibility and esterase zymograms were studied for three strains of the hawthorn spider mite, Tetranychus viennensis Zacher, collected from apple, cherry and deciduous oak trees, respectively. The host ranges for the apple and cherry strains of mites were similar, but were different from the host range for the deciduous oak strain. The intrinsic rates of natural increase $\left(r_{m}\right)$ for the apple and deciduous oak strains were similar, but slightly lower than the value for the cherry strain, showing no clear difference in $r_{m}$ between the two rosaceous strains and the deciduous oak strain. Each strain produced both female and male progeny. Inter-strain crosses between the apple and cherry strains also produced both sexes, but either of these strains produced only male progeny when paired with the deciduous oak strain, suggesting that the former were reproductively incompatible with the deciduous oak strain. Among the 8 esterase bands detected in mites, one (E7) was common for all the three strains, and another band (E1) appeared only in the cherry strain. Three other bands were exclusively found in both the apple and cherry strains. The rest were found only in the deciduous oak strain. These results clearly suggest that the apple and cherry strains on rosaceous trees constitute one species while the deciduous oak strain from fagaceous trees belongs to another.
\end{abstract}

Key Words: Acari, Tetranychus viennensis, Tetranychus quercivorus, reproductive isolation, host range, sibling species

\section{INTRODUCTION}

Some species of phytophagous mites and insects consist of several races or forms which are morphologically similar but differ from one another in host plant specificity (Diehl and Bush, 1984). It is sometimes quite difficult to determine whether or not they are host races. In some cases, the supposed host races are found to be completely 
isolated sibling species (Menken and Ulenberg, 1987). To approach this problem, careful morphological, physiological, ecological and genetic studies are indispensable. In particular, the zymogram technique is superior in separating sibling species (Menken, 1989), so that allozyme data can be most useful when evaluated together with the results from crossing experiments.

The hawthorn spider mite, Tetranychus viennensis Zacher, is a pest of rosaceous fruit trees such as apple, cherry and pear, and also found on fagaceous trees such as deciduous oak (Ehara, 1956; Jeppson et al., 1975; Gotoh, 1984). In Japan, this species has some variations in ovipositing behaviour, body colour of male adults and the terminal shape of peritreme (Gotoh, 1986). Mites collected from apple and cherry lay eggs on webs and the distal part of peritreme is larger and complicated. Mites from deciduous oak, on the other hand, lay eggs directly on leaf surface and cover eggs individually with silky thread, and they have a smaller and simpler structure of maze-shaped peritreme. Male adults of the former are reddish in colour, whereas those of the latter are pale yellowish green. Furthermore, the intrinsic rate of natural increase $\left(r_{m}\right)$ is relatively lower for mites from apple trees than for mites from deciduous oaks (Skorupska and Boczek, 1984a; Gotoh, 1986), which may reflect the peculiarity of mites infesting different plants. Although these are considered to be intraspecific variation, it has not been adequately inspected whether the strains associated with different hosts represent different species or simply different races of one species. In the present study, we compared the developmental performance on various plants, parameters on population growth and reproductive compatibility among three strains collected from apple, cherry and deciduous oak, respectively. Further, esterase zymograms among them were investigated to evaluate genetic differentiation.

\section{MATERIALS AND METHODS}

Mites: Mites were collected from apple, Malus pumila var. dulcissima Koidz., cherry, Prunus yedoensis Matsum., and deciduous oak, Quercus mongolica var. grosseserrata (Blume) (Fig. 1). Mites originating from different host plants and localities were kept in different rearing units. These laboratory stocks were maintained on leaf discs of the appropriate host plants placed on water-soaked cotton in petri dishes $(9 \mathrm{~cm} \mathrm{diam}$.) at a 16L-8D photoperiod, $25 \pm 1^{\circ} \mathrm{C}$ and $60-70 \% \mathrm{R}$. H. All investigations were carried out under the same conditions.

Developmental success on various plants: Developmental performance of mites collected from apple in Morioka (No. 4 in box; Fig. 1), cherry in Inzai (No. 5 in triangle) and deciduous oak in Tsukuba (No. 35 in circle) was examined on 55 different plants listed in Table 1. These mites will be called the apple, cherry and deciduous oak strains, respectively. About 20 newly hatched larvae of each strain were randomly sampled from the stock cultures and placed on each of 3 to 5 leaf discs of test plants. All leaf discs were checked daily to record the number of surviving individuals and their developmental stages until they reached adulthood.

Reproductive rate: Twenty females were allowed to lay eggs onto a leaf disc during 
a $24 \mathrm{hr}$ period. After hatching, larvae were singly reared on a fresh leaf disc $\left(\mathrm{ca} .4 \mathrm{~cm}^{2}\right)$. These larvae were checked every day and the developmental stages recorded. When a female deutonymph emerged, one male adult was introduced onto the leaf disc for mating, and removed $48 \mathrm{hr}$ after adult emergence of the female. The number of eggs laid by the female was recorded daily.

To assess the sex ratio of the offspring, teleiochrysalis females were paired with males on leaf discs, and allowed to oviposit for ten days. The eggs obtained from each female were observed for hatchability, and sex ratio at adult emergence was determined for the hatched individuals. The intrinsic rate of natural increase $\left(r_{m}\right)$ and other population parameters were also calculated according to the equations given by Birch (1948).

Crossing experiments: To examine reproductive compatibility among the three strains, special leaf discs were designed and used. When two strains from different hosts were crossed, two halves of different host leaves (each $8 \mathrm{~cm}^{2}$ ) were joined with vinyltape and the space between the leaves and vinyltape was filled with wax. Females in the teleiochrysalis stage obtained from each stock culture were individually transferred onto leaf discs and kept with two adult males of either the same or a different strain or without any male. The males were removed 2 days after the females emerged as adults. After initiating oviposition, each female was allowed to lay eggs for 5 days on leaf discs, and then removed from the discs. The leaf discs were checked every day to determine sex ratios of the offspring.

Esterase activity: A discontinuous polyacrylamide gel electrophoresis system was used, and the resolving gel was $1 \mathrm{~mm}$ in thickness and $40 \mathrm{~mm}$ in length. Individual adult females were homogenized in $10 \mu \mathrm{l}$ of $40 \%$ (w/v) sucrose with $1 \%$ Triton X-100 by glass rod. Five $\mu \mathrm{l}$ of each homogenized sample were loaded per gel lane. Electrophoresis was carried out at constant current $(11 \mathrm{~mA})$ for about $2 \mathrm{hr}$ on $7.5 \%$ polyacrylamide vertical slab gel. Esterases were visualized by staining for $30 \mathrm{~min}$ with $0.93 \%$ $(\mathrm{w} / \mathrm{v}$ ) ethanol solution of $\alpha$ - and $\beta$-naphtylacetate in $0.2 \mathrm{M}$ phosphate buffer, $\mathrm{pH} 8.04$, that contained $0.5 \%(\mathrm{w} / \mathrm{v})$ Fast Blue RR salt. As the isozyme patterns are not different either in $\alpha$-or $\beta$-naphtylacetate, the two substrates were mixed for making the reaction more distinct. For each local population of the three strains, more than 20 individuals were used for analyses.

Data were analysed by one-way analysis of variance (ANOVA) and means were separated by Duncan's multiple range tests. The arcsin-transformed values were used for analysing percentages of hatchability, sex ratio and survival rate.

Voucher specimens of each strain used here have been deposited in the Biological Institute (Prof. S. Ehara), Faculty of Education, Tottori University, Tottori, Japan.

\section{RESULTS}

\section{Developmental success on various plants}

Table 1 shows developmental success on various plants for the three strains. The chestnut rose, Rosa hirtura (Regel), was the only plant on which all three strains were able to reach adulthood in more than $70 \%$ of the individuals. Mites from apple trees 


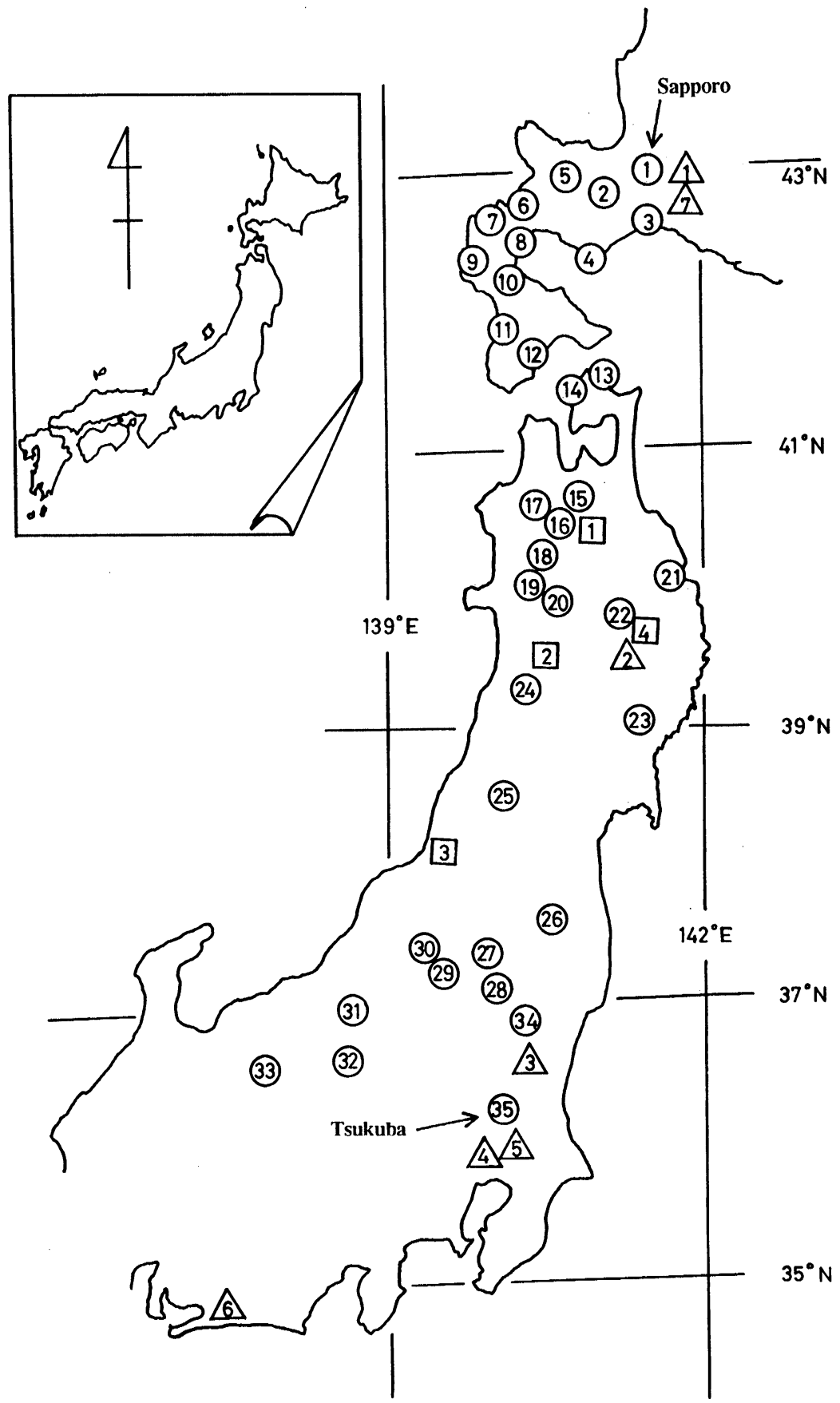

Fig. 1. Localities of Tetranychus viennensis populations used in this study. Boxes, triangles and circles indicate the mites collected from apple, cherry and deciduous oak trees, respectively. 
Table 1. Developmental success from larva to adult on various plants in three $T$. viennensis strains

\begin{tabular}{|c|c|c|c|c|c|c|}
\hline \multirow{2}{*}{ Test plant ${ }^{1}$} & \multicolumn{2}{|c|}{ Apple } & \multicolumn{2}{|c|}{ Cherry } & \multicolumn{2}{|c|}{ Deciduous oak } \\
\hline & \multicolumn{2}{|c|}{$\%$} & $\%$ & arity & $\%$ & Maturity \\
\hline \multicolumn{7}{|l|}{ Rosaceae } \\
\hline Amelanchier asiatica (Sieb. et Zucc.) & 71.2 & $(52)^{2}$ & 0 & $(40)$ & 0 & $(54)$ \\
\hline Chaenomeles speciosa (Sweet) & 94.2 & $(52)$ & 96.0 & $(50)$ & 0 & $(52)$ \\
\hline Crataegus laevigata (Poir.) & 88.5 & $(52)$ & 96.0 & $(50)$ & \multicolumn{2}{|c|}{$54.0(100)$} \\
\hline Cydonia sinensis Thouin & 0 & $(52)$ & 0 & $(52)$ & 0 & $(52)$ \\
\hline Kerria japonica (L.) & 0 & $(52)$ & 0 & $(50)$ & 0 & $(50)$ \\
\hline Malus micromalus Makino* & 84.6 & $(52)$ & 94.0 & $(50)$ & 0 & $(52)$ \\
\hline M. pumila var. dulcissima Koidz.* & 96.2 & $(52)$ & 96.2 & $(52)$ & 0 & $(51)$ \\
\hline M. sieboldii var. sieboldii (Matsum.) & 82.7 & $(52)$ & 83.3 & $(48)$ & 0 & $(50)$ \\
\hline Pourthiaea villosa var. zollingeri (Decne.) & 0 & $(52)$ & \multicolumn{2}{|c|}{$6.7(104)$} & 0 & $(53)$ \\
\hline Prunus mume Sieb. et Zucc. & 100.0 & $(52)$ & 100.0 & $(57)$ & 14.0 & $(50)$ \\
\hline P. persica (L.) & 70.0 & $(50)$ & 82.0 & $(50)$ & 0 & $(51)$ \\
\hline P. salicina Lindl. & 94.1 & $(51)$ & 87.8 & $(49)$ & 0 & $(50)$ \\
\hline P. yedoensis Matsum. & 94.3 & $(53)$ & 100.0 & $(53)$ & 0 & $(50)$ \\
\hline Pyrus serotina Rehder* & 98.1 & $(53)$ & 96.3 & $(54)$ & 0 & $(50)$ \\
\hline Rhaphiolepis umbellata var. integerrima (Hook. et Arm.) & 0 & $(50)$ & 0 & $(50)$ & 0 & $(50)$ \\
\hline Rhodotypos scandens (Thunb.) & 0 & $(50)$ & 0 & $(50)$ & 0 & $(50)$ \\
\hline Rosa hirtula (Regel) & 90.4 & $(52)$ & 80.6 & $(62)$ & 84.0 & $(50)$ \\
\hline R. rugosa Thunb. & 0 & $(52)$ & 0 & $(75)$ & 0 & $(50)$ \\
\hline Rubus buergeri Miq. & 76.5 & $(51)$ & 72.0 & $(50)$ & 23.1( & $(104)$ \\
\hline R. parvifolius L. & 0 & $(50)$ & 0 & $(48)$ & 0 & $(50)$ \\
\hline Sorbaria kirilowii (Regel) & 100.0 & $(52)$ & 70.0 & $(50)$ & 0 & $(50)$ \\
\hline Sorbus alnifolia (Sieb. et Zucc.) & 86.5 & $(52)$ & 82.0 & $(50)$ & 12.8 & $(86)$ \\
\hline S. commixta Hedl. & 96.2 & $(52)$ & 93.2 & $(44)$ & 0 & $(48)$ \\
\hline Spiraea japonica L.f. & 0 & $(52)$ & 0 & $(50)$ & 0 & $(50)$ \\
\hline Stephanandra tanakae Fr. et Sav. & 0 & $(50)$ & 0 & $(50)$ & 0 & $(54)$ \\
\hline \multicolumn{7}{|l|}{ Ulmaceae } \\
\hline Aphananthe aspera (Thunb.) & 0 & $(52)$ & 0 & $(50)$ & 0 & $(50)$ \\
\hline Celtis sinensis var. japonica (Planch.) & 0 & $(52)$ & 0 & $(46)$ & 0 & $(50)$ \\
\hline Ulmus japonica (Rehd.) & 0 & $(50)$ & 0 & $(50)$ & 0 & $(50)$ \\
\hline Zelkova serrata (Thunb.) & 0 & $(52)$ & 0 & $(50)$ & 0 & $(48)$ \\
\hline \multicolumn{7}{|l|}{ Moraceae } \\
\hline Morus bombycis Koidz.* & 0 & $(52)$ & 0 & $(60)$ & 0 & $(92)$ \\
\hline \multicolumn{7}{|l|}{ Calycanthaceae } \\
\hline Chimonanthus praecox (L.) & 0 & $(52)$ & 0 & $(50)$ & 0 & (52) \\
\hline \multicolumn{7}{|l|}{ Vitaceae } \\
\hline Ampelopsis brevipedunculata (Maxim.) & 0 & $(52)$ & 0 & $(40)$ & 56.6 & $6(76)$ \\
\hline
\end{tabular}


Table 1. Continued

\begin{tabular}{|c|c|c|c|c|c|c|}
\hline \multirow[b]{2}{*}{ Test plant $^{1}$} & \multicolumn{2}{|c|}{ Apple } & \multicolumn{2}{|c|}{ Cherry } & \multicolumn{2}{|c|}{ Deciduous oak } \\
\hline & \multicolumn{2}{|c|}{$\%$} & \multicolumn{2}{|c|}{$\%$} & \multicolumn{2}{|c|}{$\begin{array}{c}\% \\
\text { Maturity }\end{array}$} \\
\hline \multicolumn{7}{|l|}{ Fagaceae } \\
\hline Castanea crenata Sieb. et Zucc. & 0 & $(52)^{2}$ & 0 & $(61)$ & 86.0 & $(50)$ \\
\hline Fagus crenata Blume & 0 & $(52)$ & 0 & $(50)$ & 0 & $(52)$ \\
\hline F. japonica Maxim. & 0 & $(52)$ & 0 & $(50)$ & 23.1 & (104) \\
\hline Quercus acutissima Carruth. & 0 & $(52)$ & 0 & $(47)$ & 68.6 & $(51)$ \\
\hline Q. dentata Thunb. & 0 & $(50)$ & 0 & $(52)$ & 98.0 & $(50)$ \\
\hline Q. glauca Thunb. & 0 & $(52)$ & 0 & $(46)$ & 0 & $(52)$ \\
\hline Q. mongolica var. grosseserrata (Blume) & 0 & $(51)$ & 0 & $(50)$ & 78.3 & $(46)$ \\
\hline Q. myrsinaefolia Blume & 0 & $(52)$ & 0 & $(51)$ & 0 & $(52)$ \\
\hline Q. serrata Thunb. & 0 & $(51)$ & 0 & $(50)$ & 77.4 & $(53)$ \\
\hline \multicolumn{7}{|l|}{ Betulaceae } \\
\hline Alnus hirsuta var. sibirica (Fisch.) & 0 & $(40)$ & 0 & $(50)$ & 0 & $(50)$ \\
\hline A. japonica (Thunb.) & 0 & $(50)$ & 0 & $(50)$ & 0 & $(50)$ \\
\hline Betula grossa Sieb. et Zucc. & 0 & $(50)$ & 0 & $(51)$ & 0 & $(50)$ \\
\hline B. platyphylla var. japonica (Miq.) & 2.0 & $(50)$ & 2.0 & $(50)$ & 0 & $(50)$ \\
\hline Carpinus cordata Blume & 0 & $(50)$ & 6.0 & $(50)$ & 86.0 & $(50)$ \\
\hline C. tschonoskii Maxim. & 0 & $(50)$ & 0 & $(50)$ & 0 & $(50)$ \\
\hline Corylus heterophylla var. thunbergii Blume & 93.7 & $(95)$ & 82.0 & $(100)$ & 20.0 & $(100)$ \\
\hline Ostrya japonica Sarg. & 0 & $(50)$ & 0 & $(51)$ & 0 & $(50)$ \\
\hline \multicolumn{7}{|l|}{ Tiliaceae } \\
\hline Tilia $\times$ europaea $\mathrm{L}$. & \multicolumn{2}{|c|}{$23.0(100)$} & \multicolumn{2}{|c|}{$1.0(100)$} & 0 & $(100)$ \\
\hline T. maximowicziana Shirasawa & 0 & $(50)$ & 4.0 & $(50)$ & 0 & $(50)$ \\
\hline \multicolumn{7}{|l|}{ Platanaceae } \\
\hline Platanus $\times$ hybrida Brot. & 0 & $(50)$ & 0 & $(50)$ & 0 & $(50)$ \\
\hline \multicolumn{7}{|l|}{ Hippocastanaceae } \\
\hline Aesculus turbinata Blume & 0 & $(52)$ & 0 & $(50)$ & 0 & $(50)$ \\
\hline \multicolumn{7}{|l|}{ Juglandaceae } \\
\hline Juglans ailanthifolia Carriere & 0 & $(52)$ & 0 & $(63)$ & 0 & $(50)$ \\
\hline Pterocarya rhoifolia Sieb. et Zucc. & 0 & $(52)$ & 0 & $(60)$ & 0 & $(50)$ \\
\hline
\end{tabular}

1 The nomenclature of the plants was primarily according to Kurokawa (1988), but partly follows Maekawa et al. (1977) (shown with asterisks).

${ }^{2}$ Numbers in parentheses indicate the number of larvae tested.

developed successfully ( $>70 \%$ of the individuals) on sixteen species of Rosaceae and hazel, Corylus heterophylla var. thunbergii Blume, but no other plants. The cherry strain also did well on the same plants except for the Japanese shadbush, Amelanchier asiatica (Sieb. et Zucc.). Besides the chestnut rose, the deciduous oak strain was able to mature on four fagaceous species and hornbeam, Carpinus cordata Blume.

\section{Reproductive rate}

In the three $T$. viennensis strains, duration of the total development including the egg 
Table 2. Duration in days of the various stages and reproductive rate of three $T$. viennensis strains at $25^{\circ} \mathrm{C}^{1,2}$

\begin{tabular}{|c|c|c|c|c|}
\hline & Apple & Cherry & Deciduous oak & $\mathrm{F}$ ratio \\
\hline Egg 우 & $4.1 \pm 0.05(35)^{b}$ & $4.2 \pm 0.06(38)^{\mathrm{b}}$ & $5.1 \pm 0.04(36)^{\mathrm{a}}$ & $105.16^{* *}$ \\
\hline$\hat{\delta}$ & $4.5 \pm 0.13(15)^{b}$ & $4.1 \pm 0.07(14)^{c}$ & $5.1 \pm 0.09(15)^{\mathrm{a}}$ & $26.42^{* *}$ \\
\hline Immature stage & $7.2 \pm 0.10(35)^{\mathrm{a}}$ & $6.3 \pm 0.09(38)^{\mathrm{c}}$ & $6.8 \pm 0.09(36)^{b}$ & $22.68^{* *}$ \\
\hline (larva and nymph) $\hat{\delta}$ & $6.3 \pm 0.16(15)^{\mathrm{a}}$ & $5.9 \pm 0.20(14)^{\mathrm{ab}}$ & $5.6 \pm 0.13(15)^{b}$ & $5.23^{* *}$ \\
\hline Total developmental period 우 & $11.3 \pm 0.08(35)^{\mathrm{b}}$ & $10.3 \pm 0.09(38)^{\mathrm{c}}$ & $11.8 \pm 0.09(36)^{\mathrm{a}}$ & $74.65^{* *}$ \\
\hline (from egg to adult) & $10.9 \pm 0.17(15)^{\mathrm{a}}$ & $9.9 \pm 0.20(14)^{b}$ & $10.7 \pm 0.12(15)^{\mathrm{a}}$ & $9.70^{* *}$ \\
\hline Preoviposition period & $1.8 \pm 0.09(24)^{\mathrm{a}}$ & $1.3 \pm 0.09(25)^{\mathrm{b}}$ & $1.5 \pm 0.11(23)^{\mathrm{a}}$ & $69.37 * *$ \\
\hline Oviposition period & $28.0 \pm 1.28(24)^{\mathrm{b}}$ & $32.1 \pm 1.24(25)^{\mathrm{a}}$ & $21.5 \pm 1.60(23)^{\mathrm{c}}$ & $15.02^{* *}$ \\
\hline Postoviposition period & $1.0 \pm 0.23(24)$ & $0.7 \pm 0.18(25)$ & $0.6 \pm 0.15(23)$ & 0.94 \\
\hline Female longevity & $30.7 \pm 1.32(24)^{\mathrm{a}}$ & $34.1 \pm 1.27(25)^{\mathrm{a}}$ & $23.7 \pm 1.59(23)^{\mathrm{b}}$ & $14.48^{* * *}$ \\
\hline Total fecundity & $84.6 \pm 4.20(24)^{\mathrm{b}}$ & $103.2 \pm 4.06(25)^{\mathrm{a}}$ & $75.9 \pm 4.49(23)^{\mathrm{b}}$ & $14.69 * *$ \\
\hline Number of eggs per day & $3.0 \pm 0.07(24)^{\mathrm{c}}$ & $3.4 \pm 0.09(25)^{\mathrm{b}}$ & $3.7 \pm 0.12(23)^{\mathrm{a}}$ & $11.37 * *$ \\
\hline Hatchability $^{3}$ & $95.4 \pm 1.17(20)$ & $97.7 \pm 0.58(21)$ & $96.5 \pm 1.00(16)$ & 0.61 \\
\hline Sex ratio $(\text { 우 } /(\text { 우 }+\hat{\delta}))^{3}$ & $87.4 \pm 0.91(20)^{\mathrm{a}}$ & $87.3 \pm 0.65(21)^{\mathrm{a}}$ & $81.0 \pm 1.33(16)^{\mathrm{b}}$ & $11.82^{* *}$ \\
\hline
\end{tabular}

1 Mean \pm S.E. Values with $* *$ significantly different $(p<0.01$; one-way analysis of variance, ANOVA). Means for each trait across rows followed by different letters are significantly different at $p<0.05$ (Duncan's multiple range test).

2 Numbers in parentheses indicate the numbers of individuals tested.

3 Values based on eggs laid during the first 10 days of the oviposition peirod.

and immature stages was longer in females than in males ( $t$-test, for all cases, $p<0.01$; Table 2).

The oviposition period was the longest in the cherry strain, followed by the apple strain (Duncan's test, $p<0.05$; Table 2). The apple and cherry strains lived longer as adults than the deciduous oak strain. However, no significant difference was observed in the total number of eggs per female between the apple and deciduous oak strains (Duncan's test, $p>0.05$ ). This was because daily egg production in the apple strain was significantly lower than that in the deciduous oak strain (Duncan's test, $p<0.05$ ).

When the cherry strain was reared on apple leaves, the mean number of eggs laid during the first 10 days ( $33.0 \pm 0.76$ eggs $/$ o $)$ was similar to that of the apple strain reared

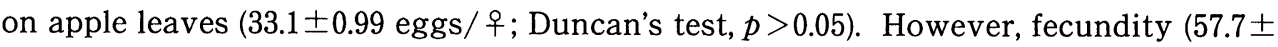
1.50 eggs ( ㅇ) of the apple strain developed on cherry leaves was greater than that of the cherry strain reared on cherry leaves $(41.2 \pm 0.98 \mathrm{eggs} /$ + ; Duncan's test, $p<0.05)$. Thus the number of eggs laid by mites of each strain was influenced by host plants, and cherry leaves were more favourable than apple leaves (ANOVA, $F=109.6, p<0.01$ ).

No difference was found in hatchability of eggs among the three strains (ANOVA, $F$ $=0.61, p>0.05$; Table 2). Sex ratio in the apple and cherry strains differed significantly from that in the deciduous oak strain (Duncan's test, $p<0.05$ ).

Figure 2 shows that the daily egg production reached a peak on the 18th day (3.4 


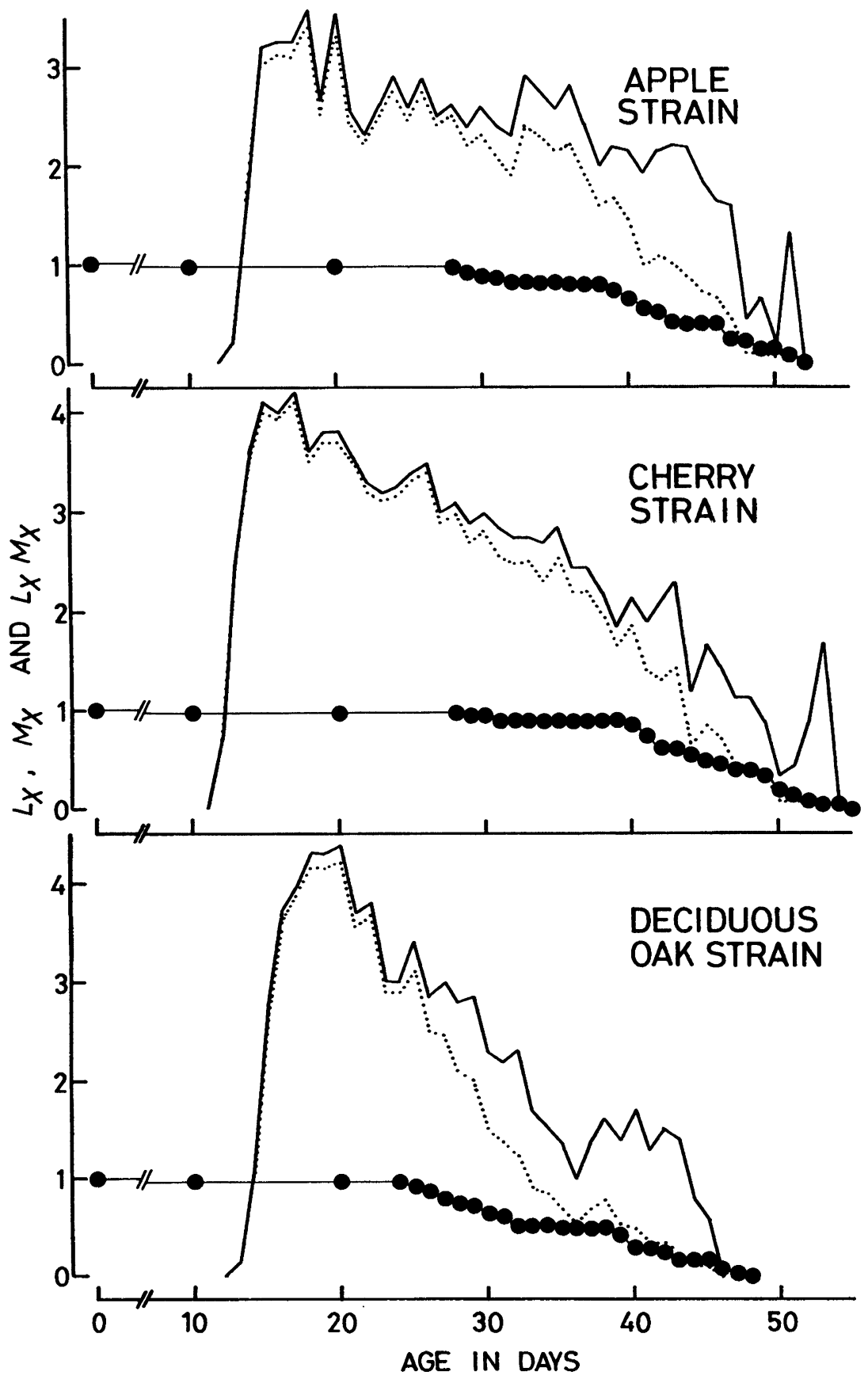

Fig. 2. The age-specific survival rate $\left(l_{x}\right)$, age-specific fecundity rate $\left(m_{x}\right)$ and $l_{x} m_{x}$ curves in three strains of $T$. viennensis. - - : $l_{x},-\cdots: m_{x}, \cdots \cdots \cdot l_{x} m_{x} . l_{x}=$ proportion of females alive at age $x . m_{x}=$ (proportion of females) $\times$ (age-specific oviposition). 
Table 3. Parameters related to potential rates of population increase in three strains of T. viennensis at $25^{\circ} \mathrm{C}$

\begin{tabular}{lccc}
\hline & Apple & Cherry & Deciduous oak \\
\hline Net reproductive rate, $R_{0}$ & 70.74 & 91.05 & 59.95 \\
Intrinsic rate of natural increase, $r_{m}$ in days ${ }^{-1}$ & 0.195 & 0.222 & 0.199 \\
Mean generation time, $T$ in days & 27.39 & 26.50 & 23.66 \\
Finite rate of increase, $\lambda$ & 1.22 & 1.25 & 1.22 \\
\hline
\end{tabular}

eggs/ ㅇ /day), the 17th day (4.2 eggs/우/day) and the 20th day (4.4 eggs/ o /day) in the apple, cherry and deciduous oak strains, respectively. Oviposition also lasted longer in the former two strains than in the latter (Duncan's test, $p<0.05$ ).

The values of $R_{0}$ and $T$ were higher in the apple and cherry strains than in the deciduous oak strain (Table 3). However, the values of $r_{m}$ and $\lambda$ for the apple and deciduous oak strains were similar but these were lower than those in the cherry strain.

\section{Crossing experiments}

The total number of eggs laid per female in the intra-strain crosses varied from 13 to 21 (Table 4). Hatchability was more than $90 \%$, and most hatchlings attained maturity in all strains. The adult sex ratio's $(ㅇ /(+\circ+\hat{\gamma}))$ in the intra-strain crosses differed significantly (Duncan's test, $p<0.05$ ). It was higher in the apple and cherry strains than in the two populations of the deciduous oak strain.

Reciprocal crosses between the Tsukuba and Sapporo populations of the deciduous oak strain gave quite different results (Table 4). Crosses between females of the Tsukuba population and males of the Sapporo population showed a high rate of hatchability $(>90 \%)$, as in the intra-population crosses. However, the reciprocal cross resulted in much lower rate of egg hatchability and extremely low sex ratios, although the juvenile survival rates were high. Because virgin females of the Sapporo population showed high rates of hatchability and survival in juvenile stages, it is inferred that the low hatchability and sex ratio were due to a high mortality of fertilized eggs.

In the reciprocal crosses between the apple and cherry strains, there was no significant reduction in egg production and egg hatchability, and the sex ratios were high (Table 4). When each of these strains was paired with the Tsukuba population of the deciduous oak strain, no female was obtained (Table 4). Because virgin females produced only males, there seemed to be a pre-zygotic reproductive barrier between the Tsukuba population of the deciduous oak strain and either of the apple or cherry strain.

\section{Esterase isozyme}

Isozyme studies were done with populations collected in widely separated localities (Fig.1). Four populations from apple, seven from cherry and 35 from deciduous oak were used. Isozyme patterns of populations from the same host plant species appeared similar, whereas those of different host plant strains were strikingly different (Figs. 3 and 4). 
Table 4. Number of eggs laid during the first 5 days of oviposition, hatchability, survival rate of immatures and sex ratio in the $\mathrm{F}_{1}$ progeny from crosses between strains of $T$. viennensis ${ }^{1,2}$

\begin{tabular}{|c|c|c|c|c|c|c|}
\hline \multicolumn{2}{|c|}{ Cross } & \multirow{2}{*}{$\begin{array}{c}\text { No. of } \\
\text { pairs tested }\end{array}$} & \multirow{2}{*}{$\begin{array}{l}\text { Total no. } \\
\text { eggs/우 }\end{array}$} & \multirow{2}{*}{$\begin{array}{l}\text { Hatchability } \\
\text { (\%) }\end{array}$} & \multirow{2}{*}{$\begin{array}{l}\text { Survival rate (\%) } \\
\text { in immature stage }\end{array}$} & \multirow{2}{*}{$\begin{array}{l}\text { Sex ratio } \\
(ㅇ ㅜ /(ㅇ+(+\hat{\delta}))\end{array}$} \\
\hline Female & Male & & & & & \\
\hline Apple & Apple & 23 & $19.5 \pm 0.53^{b}$ & $94.2 \pm 7.24^{\mathrm{bc}}$ & $97.6 \pm 3.92^{\mathrm{a}}$ & $86.4 \pm 4.77^{\mathrm{a}}$ \\
\hline Cherry & Cherry & 21 & $21.1 \pm 0.73^{\mathrm{ab}}$ & $97.9 \pm 3.62^{\mathrm{a}}$ & $98.3 \pm 2.90^{\mathrm{a}}$ & $84.3 \pm 3.49^{\mathrm{a}}$ \\
\hline Deciduous oak (T) & Deciduous oak $(\mathrm{T})$ & 19 & $17.9 \pm 0.79^{b}$ & $94.6 \pm 6.64^{\mathrm{abc}}$ & $97.1 \pm 4.59^{\mathrm{a}}$ & $78.8 \pm 6.50^{\mathrm{b}}$ \\
\hline Deciduous oak (S) & Deciduous oak (S) & 22 & $13.3 \pm 0.52^{\mathrm{d}}$ & $91.2 \pm 7.74^{\mathrm{c}}$ & $93.3 \pm 6.59^{\mathrm{ab}}$ & $78.3 \pm 7.45^{\mathrm{b}}$ \\
\hline Deciduous oak (T) & Deciduous oak (S) & 23 & $15.5 \pm 0.77^{\mathrm{c}}$ & $91.6 \pm 9.33^{c}$ & $94.5 \pm 7.63^{\mathrm{ab}}$ & $79.1 \pm 11.57^{b}$ \\
\hline Deciduous oak (S) & Deciduous oak (T) & 42 & $12.7 \pm 0.45^{\mathrm{d}}$ & $25.6 \pm 8.21^{\mathrm{d}}$ & $92.8 \pm 14.60^{\mathrm{ab}}$ & $1.4 \pm 6.36^{c}$ \\
\hline Apple & Cherry & 17 & $22.8 \pm 1.03^{\mathrm{a}}$ & $94.3 \pm 5.97^{\mathrm{bc}}$ & $95.2 \pm 6.43^{\mathrm{ab}}$ & $85.8 \pm 4.14^{\mathrm{a}}$ \\
\hline Cherry & Apple & 20 & $19.4 \pm 0.78^{\mathrm{b}}$ & $96.2 \pm 7.28^{\mathrm{ab}}$ & $98.0 \pm 3.36^{\mathrm{a}}$ & $82.2 \pm 3.63^{\mathrm{ab}}$ \\
\hline Apple & Deciduous oak (T) & 20 & $14.1 \pm 0.95^{\mathrm{cd}}$ & $90.5 \pm 8.27^{c}$ & $89.6 \pm 7.59^{\mathrm{b}}$ & 0 \\
\hline Deciduous oak $(\mathrm{T})$ & Apple & 18 & $20.8 \pm 0.91^{\mathrm{ab}}$ & $92.0 \pm 6.04^{c}$ & $90.8 \pm 7.49^{b}$ & 0 \\
\hline Cherry & Deciduous oak (T) & 20 & $21.1 \pm 0.95^{\mathrm{ab}}$ & $94.6 \pm 6.00^{\mathrm{bc}}$ & $94.0 \pm 4.95^{\mathrm{ab}}$ & 0 \\
\hline Deciduous oak ( $\mathrm{T}$ ) & Cherry & 17 & $15.0 \pm 0.97^{\mathrm{cd}}$ & $96.0 \pm 4.01^{\mathrm{ab}}$ & $89.5 \pm 10.99^{b}$ & 0 \\
\hline Apple & - & 15 & $13.4 \pm 0.89^{\text {cd }}$ & $96.6 \pm 3.34^{\mathrm{ab}}$ & $95.1 \pm 3.72^{\mathrm{ab}}$ & 0 \\
\hline Cherry & - & 18 & $20.0 \pm 0.57^{\mathrm{b}}$ & $99.2 \pm 1.91^{\mathrm{a}}$ & $97.7 \pm 2.73^{\mathrm{a}}$ & 0 \\
\hline Deciduous oak (T) & - & 17 & $12.1 \pm 0.64^{\mathrm{d}}$ & $99.2 \pm 2.40^{\mathrm{a}}$ & $98.1 \pm 3.78^{\mathrm{a}}$ & 0 \\
\hline Deciduous oak (S) & - & 22 & $12.1 \pm 0.33^{\mathrm{d}}$ & $96.6 \pm 4.24^{\mathrm{ab}}$ & $93.3 \pm 7.87^{\mathrm{ab}}$ & 0 \\
\hline F ratio & & & $26.80^{* *}$ & $90.46^{* *}$ & $3.35^{* *}$ & $597.59 * *$ \\
\hline
\end{tabular}

${ }^{1}$ Mean \pm S.E. Values with $* *$ significantly different $(p<0.01$; one-way analysis of variance, ANOVA). Means in a column followed by different letters are significantly different at $p<0.05$ (Duncan's multiple range test).

${ }^{2}$ (T) means the population collected from Tsukuba, Ibaraki, and (S) from Sapporo, Hokkaido. 


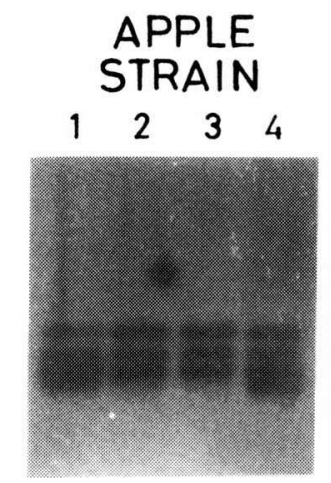

\section{CHERRY STRAIN}

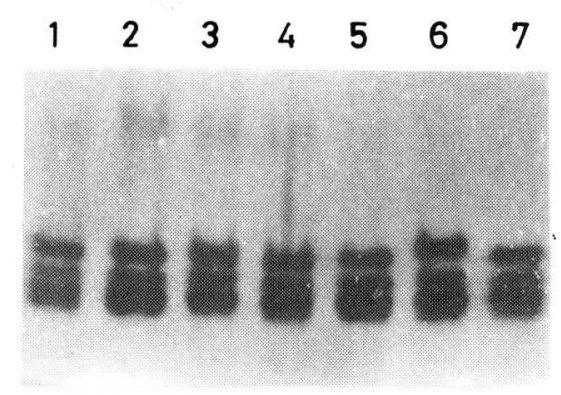

\section{DECIDUOUS OAK STRAIN}

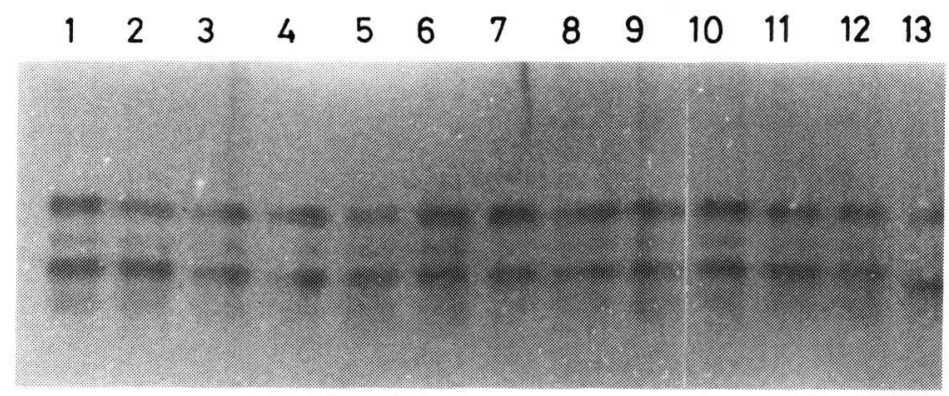

$\begin{array}{llllllllllllll}14 & 15 & 16 & 17 & 18 & 19 & 20 & 21 & 22 & 23 & 24 & 25 & 26 & 27\end{array}$

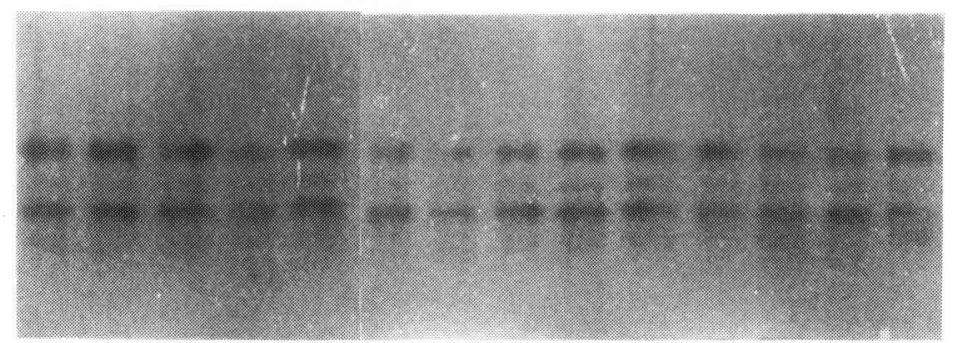

\section{$\begin{array}{llllllll}28 & 29 & 30 & 31 & 32 & 33 & 34 & 35\end{array}$}

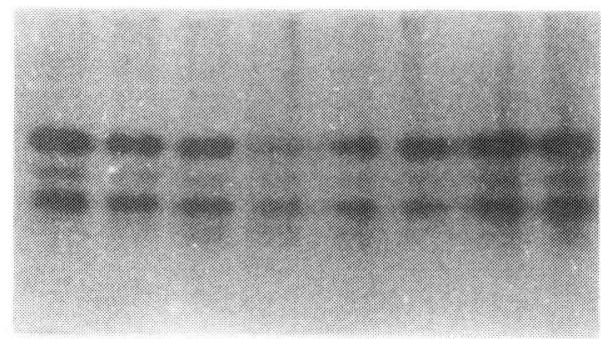

Fig. 3. Esterase zymograms of $T$. viennensis populations originating from apple, cherry and deciduous oak trees. Numbers on gel lanes indicate the locality number illustrated in Fig. 1. 

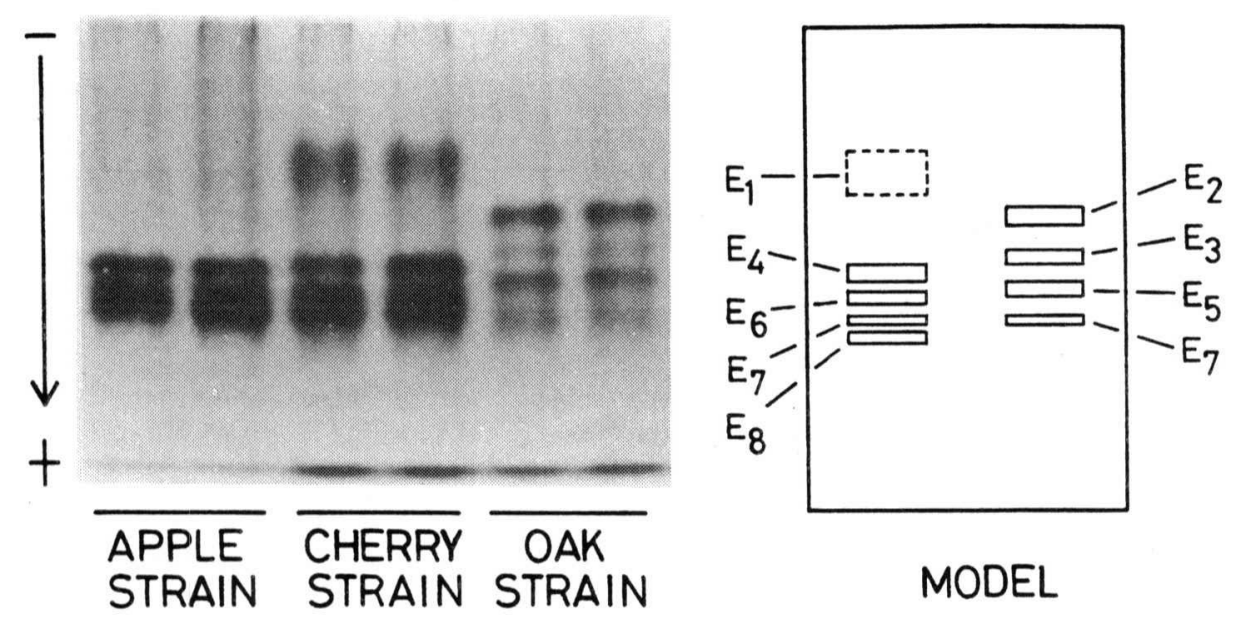

Fig. 4. Esterase zymograms of $T$. viennensis collected from different hosts, with their model pattern.

Four local populations of the apple strain showed a common isozyme pattern with 3 distinct bands apart from E8 (Figs. 3 and 4). All populations of the cherry strain also had a similar zymogram except for one population from Hamamatsu (No. 6 in Fig. 1). In this population, E4 was absent but an additional band moving slowly appeared (Fig. 3). Out of the thirty-five local populations of the deciduous oak strain examined, the one from Kazamaura (No. 13) lacked E5 for all individuals but had an additional band which moved faster than E5 (Fig. 3).

Only the E7 band was seen in all strains of T. viennensis (Fig. 4). The E1 band appeared only in the cherry strain. The apple and cherry strains showed common distinct bands of E4, E6 and E8. However, individual variation of the E8 band was observed within strains: some individuals had the E8 band and others did not (e.g., mites from an apple tree, Fig. 4). The deciduous oak strain had three other bands (E2, E3 and E5; Fig. 4).

\section{DISCUSSION}

The present study shows that the chestnut rose is the only host common in the three strains of $T$. viennensis. The two strains collected from rosaceous trees have a similar host range while the deciduous oak strain from fagaceous trees shows a different one. Mating between strains from rosaceous trees and fagaceous ones may be limited in the field, because mating of spider mites occurs on plants where they have developed.

Skorupska and Boczek (1984a, b) reported that the apple strain of T. viennensis in Poland successfully developed on rosaceous plants of Cerasus, Crataegus, Malus, Pyrus, Rubus and Sorbus, and Ribes (Saxifragaceae). In the present study, 5 more genera (Amelanchier, Chaenomeles, Rosa, Sorbaria and Corylus) that could potentially serve as 
host plants for the hawthorn spider mite from apple orchards were found.

The intrinsic rate of natural increase $\left(r_{m}\right)$ has been used widely as a criterion of life history traits and habitat utilization patterns (Stearns, 1976; Southwood, 1977). Previous reports suggest that the $r_{m}$ values were lower for mites from apple trees $\left(r_{m}=0.136\right.$; Skorupska and Boczek, 1984a) than for those from deciduous oaks $\left(r_{m}=0.172\right.$; Gotoh, 1986). However, the present study failed to support the above tendency. That is, the $r_{m}$ was greater for the cherry strain than for the apple or deciduous oak strain of $T$. viennensis, and no host-specific difference was obtained.

Although only a limited number of populations for each strains were crossed in the present study, our results clearly showed that the apple and cherry strains were reproductively compatible with each other but not with the deciduous oak strain. A similar situation in which strains differing in host specificity are reproductively incompatible with each other has been reported in the citrus red mite, Panonychus citri (McGregor) (Takafuji and Fujimoto, 1985), the European red mite, Panonychus ulmi (Koch) (Gotoh and Noguchi, 1990; Ehara and Gotoh, 1991 and 1992), the yellow peach moth, Conogethes punctiferalis (Guenee) (Shinkaji, 1969; Konno et al., 1981) and the fall armyworm, Spodoptera frugiperda (J. E. Smith) (Pashley, 1986; Pashley and Martin, 1987). The results of the present study show that the two strains from rosaceous trees and the strain from fagaceous trees are different biological entities. This conclusion is consistent with the results of morphological study by Ehara and Gotoh (1990) in which the two rosaceous strains and the fagaceous strain were considered to be $T$. viennensis and T. quercivorus Ehara et Gotoh, respectively.

In the present study, crosses between females of the Sapporo population and males of the Tsukuba population from deciduous oaks resulted in an extremely low hatchability, but in a high rate of survival in juvenile stages. On the other hand, the unfertilized eggs deposited by virgin females of the Sapporo population showed a high rate of hatchability as well as a high rate of juvenile survival. These data suggest that fertilized eggs produced by crossing are inviable and the two populations of the deciduous oak strain are not reproductively compatible. Partial reproductive incompatibility among local populations is well known in the two-spotted spider mite, Tetranychus urticae Koch (de Boer, 1979, 1980 and 1981), and insects (Thompson, 1987; Rousset and Raymond, 1991). Although this problem is of interest, we will discuss it in future papers.

Menken and Ulenberg (1987) have mentioned that electrophoretic studies can give valuable information on reproductive behaviour for the supposed examples of host races. In the present study, the esterase isozyme pattern of the deciduous oak strain is clearly different from either of the apple or cherry strain. This conforms to the results on the host range and genetic compatibility. A similar phenomenon in which esterase zymogram differs between distinct host strains can also be found in P. citri (Osakabe, 1987).

Studies on esterase zymograms show high genetic heterogeneity among local populations in P. citri (Osakabe, 1987) and in T. urticae (Sula and Weyda, 1983). However, in the present study using a similar technique, inter-populational variation for $T$. viennensis seems to be small. This may be because esterases are closely related to organopho- 
sphorus resistance and zymograms are largely variable among mites living in an agro-ecosystem. The former two species are frequently sprayed with acaricides, but the latter is not.

Acknowledgements

We wish to express our sincere gratitude to Drs. S. Tanaka, R. de Boer, L. P. S. van der Geest, M. W. Sabelis and D. P. Pashley for reading the manuscript and their comments, to Dr. M. Suzuki for identifying plants and to Messrs. T. Abe, R. Hirayama, Y. Ishikawa, M. Kakizaki, M. Morita, K. Moriya, O. Noguchi, Mh. Osakabe, S. Sakurai, T. Shimoda, Y. Takahashi, M. Wakou and M. Yamada for their kind assistance with rearing mites or collecting spider mites. Mites on deciduous oak in Tsukuba, Ibaraki, were collected in Tsukuba Botanical Garden, Natural Science Museum, with permission of the bureau.

\section{摘 要}

オウトゥハダニの 3 系統における発育特性, 生殖和合性およびェステラーゼザイモグラム 後藤哲雄・高山健志（茨城大学農学部応用動物昆虫学研究室）

オウトウハダニ Tetranychus viennensis Zacher には，周気管の形状と雄成虫の体色，産 卵習性を異にする系統が存在する。これらは種内変異と考えられているが, 詳細には検討さ れていない。本研究では, 複雑な周気管を持ちバラ科樹木に寄生するリンゴとサクラ系統, および単純な周気管を持ちブナ科樹木に寄生するミズナラ系統が同一種であるかまたは別種 であるかを明らかにする目的で，寄主範囲，増殖率，生殖和合性およびェステラーゼザイモ グラムを調査した。リンゴとサクラ系統の寄主範囲は非常によく類似していたが， ミズナラ 系統とは明らかに異なっていた。ミズナラ系統の内的自然増加率はリンゴ系統と類似した值 を示したが，サクラ系統の值よりは低く，ブナ科とバラ科寄生系統間の差は不鮮明であった。 系統内交配およびリンゴとサクラ系統間の交配では雌雄の子孫が出現し，和合性を示した が，バラ科に寄生する 2 系統とミズナラ系統の交配では雄の子孫のみが出現し，生殖的な隔 離が見られた。エステラーゼアイソザイムのバンドは，3系統に共通する 1 本 (E7) を含む 8 本が検出された。リンゴとサクラ系統では，サクラ系統に特異的な 1 本 (E1) を除き，共通す る3 本のバンドを示したが, ミズナラ系統はこれらと異なる 3 本のバンドを出現した。以上 の結果から，バラ科に寄生するリンゴとサクラ系統は同一種であるが，ブナ科に寄生するミ ズナラ系統は明らかに別種であると結論された。

\section{REFERENCES}

Birch, L. C. (1948): The intrinsic rate of natural increase of an insect population. J. Anim. Ecol., 17: $15-26$.

de Boer, R. (1979): Investigations concerning the development of reproductive incompatibilities between populations of the spider mite, Tetranychus urticae. Z. angew. Entomol., 87: 113-121.

de Boer, R. (1980): Genetic affinities between spider mite Tetranychus urticae (Acarina: Tetranychidae) populations in a non-agricultural area. Ent. exp. appl., 28: 22-28.

de Boer, R. (1981): Genetic affinities between spider mite Tetranychus urticae populations in a nonagricultural area II. Ent. exp. appl., 30: 63-67.

Diehl, S. R. and G. L. Bush (1984): An evolutionary and applied perspective of insect biotypes. Ann. 
Rev. Entomol., 29: 471-504.

Ehara, S. (1956): Some spider mites from northern Japan. J. Fac. Sci. Hokkaido Univ. Ser. 6, Zool., 12: $244-258$

Ehara, S. and T. Gotoh (1990): A new Tetranychus closely related to T. viennensis Zacher (Acari: Tetranychidae). Internat. J. Acarol., 16: 55-58.

Ehara, S. and T. Gotoh (1991): A new species of Panonychus from dwarf bamboo in Japan (Acari: Tetranychidae). Internat. J. Acarol., 17: 9-12.

Ehara, S. and T. Gotoh (1992): Descriptions of two Panonychus spider mites from Japan, with a key to the species of the genus in the world (Acari: Tetranychidae). Appl. Entomol. Zool., 27: 107-115.

Gotoh, T. (1984): Annual life cycle of the hawthorn spider mite, Tetranychus viennensis Zacher (Acarina: Tetranychidae) on deciduous oak. Jpn. J. Appl. Entomol. Zool., 28: 254-259. (In Japanese with English summary.)

Gotoh, T. (1986): Life-history parameters of the hawthorn spider mite, Tetranychus viennensis Zacher (Acarina: Tetranychidae), on deciduous oak. Appl. Entomol. Zool., 21: 389-393.

Gotoh, T. and O. Noguchi (1990): Developmental success and reproductive incompatibility among populations of the European red mite, Panonychus ulmi (Acari: Tetranychidae). Exp. Appl. Acarol., 10: 157-165.

Jeppson, L. R., H. H. Keifer and E. W. Baker (1975): Mites Injurious to Economic Plants. 614 p., University of California Press, Berkeley.

Konno, Y., H. Honda and Y. Matsumoto (1981): Mechanisms of reproductive isolation between the fruit-feeding and the Pinaceae-feeding types of the yellow peach moth, Dichocrocis punctiferalis Guenee (Lepidoptera: Pyralidae). Jpn. J. Appl. Entomol. Zool., 25: 253-258. (In Japanese with English summary.)

Kurokawa, S. (1988): A list of vascular plants in the Tsukuba Botanical Garden, 1988. Ann. Tsukuba Bot. Gard., 7: 1-120. (In Japanese)

Maekawa, F., H. Hara and T. Tuyama (1977): Makino's Illustrated Flora of Japan. 1060 p., Hokuryukan, Tokyo. (In Japanese)

Menken, S. B. J. (1989): Electrophoretic studies on geographic populations, host races, and sibling species of insect pests. In: Electrophoretic Studies on Agricultural Pests (eds., Loxdale H. D. and J. den Hollander), pp. 181-202, Clarendon Press, Oxford.

Menken, S. B. J. and S. A. Ulenberg (1987): Biochemical characters in agricultural entomology. Agric. Zool. Rev., 2: 305-360.

Osakabe, Mh. (1987): Esterase activities and developmental success of the citrus red mite, Panonychus citri (McGregor) (Acarina: Tetranychidae), on several plants. Appl. Entomol. Zool., 22: 35-44.

Pashley, D. P. (1986): Host-associated genetic differentiation in fall armyworm (Lepidoptera: Noctuidae): a sibling species complex? Ann. Entomol. Soc. Am., 79: 898-904.

Pashley, D. P. and J. A. Martin (1987): Reproductive incompatibility between host strains of the fall army worm (Lepidoptera: Noctuidae). Ann. Entomol. Soc. Am., 80: 731-733.

Rousset, F. and M. Raymond (1991): Cytoplasmic incompatibility in insects: Why sterilize females? Trends Ecol. Evol., 6: 54-57.

Shinkaji, N. (1969): Studies on the peach pyralid moth, Dichocrocis punctiferalis Guenee (Lepidoptera: Pyralidae). I. Seasonal development with special references to the difference between the fruit tree type and the conifer type. Bull. Hort. Res. Sta. Ser. A, 8: 155-208. (In Japanese with English summary.)

Skorupska, A. and J. Boczek (1984a): Biology, ecology and demographic parameters of the hawthorn spider mite (Tetranychus viennensis Zacher) on various host plants. Pr. Nauk. Inst. Ochr. Rosl., 26: 119-145.

Skorupska, A. and J. Boczek (1984b): Host-plant acceptance and preference of the hawthorn spider mite (Tetranychus viennensis Zacher). Pr. Nauk. Inst. Ochr. Rosl., 26: 147-165.

Southwood, T. R. E. (1977): Habitat, the templet for ecological strategies? J. Anim. Ecol., 46: 337- 
365.

Stearns, S. C. (1976): Life-history tactics: a review of the ideas. Q. Rev. Biol., 51: 3-47.

Sula, J. and F. Weyda (1983): Esterase polymorphism in several populations of the two-spotted spider mite, Tetranychus urticae Koch. Experientia, 39: 78-79.

Takafuji, A. and H. Fujimoto (1985): Reproductive compatibility between populations of the citrus red mite, Panonychus citri (McGregor) (Acarina: Tetranychidae). Res. Popul. Ecol., 27: 361-372.

Thompson, J. N. (1987): Symbiont-induced speciation. Biol. J. Linn. Soc., 32: 385-393. 